\title{
Contribution to animal nutrition in the Netherlands by the Research Institute for Livestock Feeding and Nutrition, since 1890
}

\author{
Y. VAN DER HONING \& S. J. LANGELAAR \\ Research Institute for Livestock Feeding and Nutrition, P. O. Box 160, NL 8200 AD Lelystad, \\ Netherlands
}

\section{Introduction}

Agriculture in the Netherlands developed successfully in the second half of the nineteenth century. This was mainly a result of increasing international demand of agricultural products due to industrialization and expanding world trade. However, these developments, especially in dairy production, promoted agricultural production in other countries too. This and the expanding margarine industry led to increased competition and higher pressure on the Dutch position on the export market. The economic progress also stimulated the consumers' attention for product quality not in the least because of adulteration (i.e. of butter) of agricultural products. The result of these trends was a declining position of the Dutch dairy products on the export market. As a result of these developments, a severe agricultural crisis developed near the end of the 19th century. This development, together with old-fashioned processes of production due to lack of adequate education, research and extension service, required active help of the government.

A study of a State Committee resulted in the advice to extend the single State Agricultural Experimental Station to 5 stations with a dual purpose: testing for quality of agricultural products and agricultural research to solve problems in practice.

Foundation, organization and research, 1890-1916

\section{Foundation and organization}

Following the advice of the Committee, one of the three State Agricultural Experimental Stations (Rijkslandbouwproefstations) was officially founded at Hoorn on the 2 nd of January: 1890 . Its task was to serve the western region of the country.

From 1889-1892 Dr C. J. van Lookeren Campagne was director. He was succeeded by Dr K. H. M. van der Zande (1892-1910) and Dr B. R. de Bruin (1910-1916).

From this station, research on dairying and animal feeding in the Netherlands has been initiated and expanded. Quality control was initially the major part of the activities. Research was only minor, due to lack of time, budget and personnel. In that 
period, increasing participation of farmers in cooperative dairies, an open eye of Dutch farmers for fertilizer application and improvement of grassland production, fodder conservation, milk yield and feed conversion developed. This led to an increasing attention of agricultural research required for all kinds of actual problems. Lack of extension service was also a reason for an increasing number of questions from practice to the stations. All stations had a laboratory for chemical analyses, but in Hoorn also a bacteriological laboratory was available. In 1893 this became a department mainly for research of dairy products for the whole country. Also in 1901 an experimental dairy farm exploited by an association of farmers was built together with the station on the outskirts of the town. Initially, facilities served dairy research only, but in 1903 also a pighouse became available.

\section{Research}

Prior to the realization of facilities at the station, agricultural experiments (i.e. feeding trails, fertilizer trials, etc.) had been executed on several private farms. 'Hoorn' started with studying the effects of feeding on volatile fatty acid content in butter. Soon also the effect of linseed cake, maizegluten, the addition of some molasses to concentrates, cottonseed-, groundnut- and soyacake on milk production and feed conversion was studied. Also the development of a milking machine was started, but tests of the first prototype were not succesful.

With pigs, molassed feeds, sugarpulp, rice bran. sweet and sour whey were tested and the effect of feeding fishmeal on carcass quality was investigated. A first digestibility trial was executed in 1916, in which attention was paid to metabolic faecal protein and the true digestibility coefficient. Besides the experiments with a practical nature, also fundamental studies got attention. Already in 1901 a goat with a permanent rumen fistula was used to measure crude fibre digestion in the rumen. Acetate, propionate and butyrate production in the rumen and disappearance of fibre proved fibre digestion.

A long study to identify the factors involved in heating of haystacks was also started in this period.

\section{Development in the period 1916-1957}

\section{Organizational}

Since 1907 the tasks of quality control and research were done in two separate departments. In 1916 all testing activities were abandoned. Quality control of fertilizers was moved to the station at Maastricht and that of animal feedstuffs to Wageningen. All research activities were concentrated at the two stations at Hoorn and Groningen. The Hoorn station concentrated on dairy and animal feeding research. Between 1916 and 1919 three departments developed, dealing with chemical, bacteriological and physiological aspects. Dr F. J. Boekhout, Dr W. van Dam and Dr E. Hekma were appointed as the first directors. In 1927 Dr E. Brouwer was appointed director of the Physiology Department. As a result, research on animal 
feeding and nutrition became an increasing part of this department. When Dr Brouwer became professor at the Agricultural University at Wageningen, Dr A. M. Frens took over in 1939. In 1947 Dr Frens was appointed general director of the station. After World War II it was decided to separate an independent institute for dairy research (NIZO) from the Hoorn institute. This decision could not be effectuated before 1949 and it took until 1954 before NIZO could move to its new facilities in Ede. The station was given a new name: State Experimental Station for Animal Nutrition and Husbandry. In 1957, it became the Institute for Livestock Feeding and Nutrition Research (IVVO). For the time being, it remained at Hoorn.

\section{Research}

In the beginning, testing of usefulness and substitution of different feeds for cattle and pigs was the major part of research. But soon ensiling of grass according to the so-called Friesian-Dutch method followed by using different types of additives in silo's extended the knowledge on fodder conservation. Anorganic acids used as an additive led to investigations in the physiological effects of these additives on the acid-base balance of cattle. Feeding trials according to the Danish principle contributed substantially to the improvement of feeding of dairy cattle in practice.

Feed evaluation, including nutritive value predicted from chemical analyses, was another important item and contributed for a long time to feeding in practice. That information was presented in the Dutch Table on feedstuffs, at first published in 1939.

Research on requirement of minerals and trace elements started as a result of health problems in reclaimed land areas (Wieringermeer) and cultivated land after removing peat or heather.

Growing pigs for bacon were tested. Afterwards testing stations for that purpose were started according to a procedure popular in Denmark.

In World War II the substitution of protein by urea, the feeding of cardboard (from straw) to dairy cattle and of potatoes to pigs were examples of the type of research in that difficult period. After World War II, research was extended rapidly as a result of a growing demand for animal feeds. Production of better quality feeds and improvement of harvesting and conservation methods aiming at lower losses became new goals of agricultural research.

\section{The final period at Hoorn from 1957-1977}

\section{Organizational}

The expanding demand for animal feeding research showed the limitations of the institute at Hoorn. The future development was studied already in the early sixties. The lack of a sufficiently large area for grassland and fodder production to maintain a large high-yielding dairy herd led to the recommendation that the institute should move to another location. Dr Frens left in 1964 and succeeded Prof Brouwer in Wageningen. Ir F. de Boer was appointed as director.

The plan to move was executed after the decision on the new location at Lelystad 
was made. Here, reclaimed land from the IJsselmeer provided the required area for grassland and arable land for the institute. In 1970 a start was made with building the farm. Gradually the construction of the other parts of the institute followed. A metabolism unit for digestibility and energy and $\mathrm{N}$ balance trials and studies with cannulated animals was built. For financial reasons the laboratory and office facilities were located in temporary housing. This period was concluded with the closure of the location at Hoorn in August 1977.

\section{Research}

In this period the research on composition and nutritive value of all kind of feedstuffs intensified, especially with regard to the diversity in type of feedstuffs. Earlier the major interest was in forages and protein-rich supplements, but in this period a wide variety of by-products from industrial processing got attention. Animal trials were used as a reference to develop methods of prediction of digestibility from chemical analyses using regression equations. Increasing variability within categories of feedstuffs, especially by-products, underlined the importance of predicting methods. In addition, more tests with animals on the applicability of new products in ruminant or pig feeding were needed. Facilities for energy balance studies became available at Lelystad in 1976 . The rapid increase in productive capacity of dairy cattle resulted in a sharp rise in proportion of concentrates in their rations. This required more research on factors involved in feed intake, rumen fermentation, protein metabolism and digestive disorders in high-yielding cows. Especially the beginning of lactation prior to the peak of milk production got more attention. Effects of the type and origin of concentrate-mixtures (degradability of protein and carbohydrates) appeared to affect substantially intake, yield and composition of milk and incidence of digestive disorders.

Also nutrient requirements for protein of intensively fed beef cattle, in which rations also different by-products were used, were studied. Research in pig feeding was continued on digestibility and suitability of feedstuffs for growing pigs and for sows. Effects of ration on composition of growth was studied and the influence of fatty acids in dietary fat on the composition of body fat. Number and size of fat cells was related to fat deposition and mobilization of fat during growth.

With sheep the interest in more lambs per ewe by using increased lambing frequency resulted in studies on feeding of ewes during pregnancy and lactation. Especially the protein supply during suckling was studied in relation to growth rate of lambs. Also artificially rearing (i.e. lamb bar) was a research area.

A landmark at the end of this period was the introduction of a new feed evaluation system for energy in ruminants in 1977 following a proposal of Dr van Es. The system was developed from numerous date on energy balances of dairy cows and digestibility of feeds and from feeding trails with dairy and beef cattle obtained from research in the Netherlands as well as abroad (Beltsville, Rockstock). 


\section{Period 1977-1989}

\section{Organizational}

On 22 September 1977 the new institute at Lelystad was officially opened. Approval for building a small pig unit was obtained at that occasion too, which came into operation in 1978. The Association to Exploit an Experimental Dairy Farm at Hoorn had its final meeting on 1 Februari 1979. For almost 80 years this association provided the institute's animal facilities.

Unfortunately, the new temporarily housed laboratory was lost in a fire on 13 January 1979. Due to intensive cooperation between the institutions the laboratory was rebuild. A permanent housing was constructed, which was opened in 1981 .

On 1 July 1985 Ir F. de Boer retired after 20 years as director of the institute. Prof Dr Ir A. J. H. van Es took over temporarily until 1 November 1985, when Dr Ir Y. van der Honing was appointed as director.

In 1982, plans to improve the pig unit were sent to the Ministry of Agriculture, but it took until 1989 before approval and funds to execute the plan were obtained. In 1987 a commission for the Construction of Permanent Office-Building was set up. Here the IVVO, as well as the Research Station for Cattle, Sheep and Horse Husbandry and the Central Extension Service for Animal Husbandry were to be housed. At the end of 1989, IVVO and the research station could move to the new offices.

\section{Research}

In this period, animal production in the Netherlands continued to intensify, resulting in many questions on nutrition and feeding strategy. In fact this required more research capacity than was available, but for budgetary reasons the Ministry of Agriculture and Fisheries lowered the increase in staff of the institute as promised in the sixties and propagated intensive cooperation with institutes in related fields and obtaining sponsored projects. In the end it reduced the total number of regular personnel to only 70 (instead of 120-125, as planned when developing the new facilities at Lelystad). Within these limitations, but with modern and excellent facilities, a large number of studies was undertaken. As milk yield of cows at the institute's farm increased from 5000 to $8000 \mathrm{~kg}$ per annum, all problems of high-yielding cattle had to be faced. The increasing proportion of concentrates in dairy diets (composed of various imported feedstuffs and by-products) required research on the minimal quantity of structure in the ration required to prevent low-milkfat-syndrome. Also the substitution rate of feeds for forage was intensively studied.

Research with pigs continued on digestibility measurements of many kinds of feedstuffs with regard to organic matter, energy, protein and amino acids, and minerals such as $\mathbf{P}$ and $\mathrm{Ca}$. The increasing import of feedstuffs mainly based on a large variety of by-products urged a more accurate evaluation of these feeds with rather variable composition from batch to batch. The net energy value of compound feeds rich in by-products or supplemented with fat were studied. 


\section{Feed evaluation and prediction of nutritive value}

Feed evaluation and prediction of energy and protein value became a major line of research. Digestibility measurements on forages and concentrate feedstuffs were continued, but more effort was put into various prediction methods, such as digestibility in vitro (using rumen fluid, industrial cellulases, etc.), near-infrared spectroscopy, nylon-bag incubation techniques, etc. Also energy and protein requirements of ruminants and pigs were studied. A comparison of energy evaluation systems for dairy cattle in various countries received international appreciation. Energy studies with ruminants in respiration chambres were continued with fresh grass, corn silage and concentrates-rich fat-supplemented diets.

With substantial contribution of IVVO a table of digestible amino acids in feedstuffs for pigs was produced. However, this table was based on faecal digestibility, but after sufficient information was obtained (a.o. by the TNO Institute for Animal Nutrition and Physiology in Wageningen) a preliminary table with digestibility coefficients of amino acids in feedstuffs based on ileal digestibility measurements was prepared at the end of the eighties.

Feeding trials, including growth and carcass composition, were used to improve the precision of the energy and protein requirements for growing pigs in view of the more rapid rate of gain achieved.

\section{Intake, rumen fermentation and strategy of feeding}

Feed intake is considered a limiting factor in feeding of productive animals. Hence intake regulation became the subject of a thesis in which the significance of VFA, glucose and hormones such as insulin and glucagon for feed intake was studied. Goats were prepared to measure plasma concentrations at the jugular or the portal vene.

In the seventies, methodology to perform feed intake studies under grazing conditions was developed and improved. In labour-intensive studies the intake of herbage during grazing was measured and the factors involved (herbage allowance, type and quantity of supplements), the use of corn silage as a substitute or supplement with grass were studied.

Fodder conservation received renewed attention in the institute after spores of Clostridia appeared to lower cheese quality so much that export became threatened. Also secondary fermentation in silage was studied. In the eighties, developments in biotechnology resulted in research on the effects of enzymes and inoculants to improve silage quality and to increase intake and digestibility of fibrous substances.

The home-grown forages, grass silage and corn silage, supplemented with concentrates, were used in several studies to determine optimum feeding conditions with high intake and low incidence of digestive disorders. Forage quality, forage to concentrate ratio and type and composition (protein, structural carbohydrates, nonstructural carbohydrates) of the concentrates were shown to have important effects.

The long-term strategy of feeding, especially of concentrates, was studied in feeding trials to know whether supply of concentrates according to the individual cows's daily requirement was really needed. In a more fundamental study on short-term strategy it was investigated if a more frequent feeding of concentrates in smaller por- 
tions over the day was profitable.

In the eighties, bovine somatotropine (BST) was applied in a feeding trial with high-yielding cows to quantify effects on milk production, health and fertility. It also resulted in a small study to identify the mechanism behind the increase of feed intake after BST treatment.

The importance of optimum rumen fermentation for intake and protein and energy metabolism of the ruminants was more and more realized and research in this area required a major part of the capacity. It increased our knowledge and understanding of these complex processes, which resulted in international appreciation and cooperation.

These studies included the effects of the composition of the ration, the concentrates in particular, on conditions in the fore-stomachs and lower intestines. Also measurements of rate of passage of fluid and solid particles through the reticulorumen and the intestines were made. This required tests on adequate markers in digestive studies.

The main purpose of these studies was to obtain more knowledge of the essential elements of the complicated mechanism of $\mathrm{N}$ and protein metabolism in the ruminant. Amino acid supply at the small intestine was measured in (a.o. re-entrant) cannulated cows, degradability was studied by using a nylon-bag technique, and rumen fermentation could be studied in cows equipped with a small or large cannula in the rumen wall. Also saliva production was measured after cannulation of the salivary duct. As always these more basic studies were accompanied by large-scale feeding trials with the aim to approach the situation at the farm.

The reduction of the risks of acetonaemia during pregnancy of sheep was investigated by shearing of pregnant sheep. Especially the effects on intake of forage were studied.

\section{Reduction of environmental polluttion}

The major problem of the eighties was the pollution of the environment by manure. This had to be decreased and at least part of its solution had to be achieved by lowering the excretion of minerals and nitrogen by ruminants, pigs and poultry as a result of a change in animal feeding. Initially the reduction of phosphorus got most attention, but soon nitrogen was also considered a serious problem. A substantial reduction in $\mathrm{P}$ excretion by monogastrics could be obtained if the $\mathrm{P}$ present as phytate, for the animal useless, was made available. A lot of research in our institute was done on the effect of plant and microbial phytases. The latter were being developed by Gist-Brocades, and evaluated in close cooperation. Also a better knowledge of digestible phosphorus in feedstuffs and of the minimum requirement of $P$ in different phases of the animal's life can reduce the excretion substantially as it facilitates making $P$ supply equal to $P$ requirement. Therefore a table giving the concentration of digestible phosphorus was composed and the minimal $P$ requirements of pigs in different physiological stages and periods of the growing phase were determined. To reduce crude protein intake and nitrogen excretion of pigs, trials were carried out to assess more accurately the minimum requirement of the first four or five limiting essential amino acids after serial supplementation with lysine, methionine, etc. 
In ruminants the excess of protein supply during grazing had to be reduced. Trials to widen the energy/protein ratio in the diet involved low-protein supplements such as corn silage, beet pulp, manioc or maize as a subsitute for part of the fresh grass. Development of a model of the cow's $\mathrm{N}$ metabolism and a new protein evaluation system for ruiminants contributed to achieving a better balance between $\mathrm{N}$ and energy supply for microbes and the requirements for amino acids of the host animal.

In this period, increased attention was given to by-products, the fresh, wet instead of the dried form such as pressed beetpulp silage, brewers' grains, maize glutenfeed, etc.

Evaluation of dried poultry litter as feed for beef cattle was studied and also the possibilities of mixing or ensiling poultry litter with corn silage for beef and dairy cows were investigated.

Effect and mechanism of $\mathrm{Cu}$ supplement in pig feeds were studied but little insight in the mechanism was obtained. By EC regulations the $\mathrm{Cu}$ supplementation had to be reduced substantially, so research for alternatives became more attractive.

With regard to quality and safety of animal products, the work already started at Hoorn on the carry-over of several pesticides, PCB's, heavy metals $(\mathrm{Cd}, \mathrm{Hg}, \mathrm{Pb}$, etc.) and other contaminants from feed to milk, meat or organs was continued. After 1985 the effects of radioactive cesium (after the Tsjernobyl-disaster) and more recently the contamination of cows with dioxines and possible measures to be taken were studied.

The special issue of this journal contains contributions of research results of different aspects of the institute's work in the last years. It is to present the reader a good overview of different kinds of research which is of an applied nature, but that needs for being succesfull a good understanding of the complicated processes and mechanisms of conversion of feed into highly valuable animal products.

\section{Summarizing remarks}

From the beginning of the station at Hoorn the research aimed at solving problems in practice. This resulted always in a combined approach of actual and relevant problems in practice. More basic research to increase our knowledge and understanding of composition of feedstuffs, nutrition of farm animals and its feed conversion was often combined with feeding trails to evaluate the application in practice. The modern facilities at Lelystad are rather unique for that purpose.

Also from the early beginning of the station at Hoorn attention was paid to application of obtained results, through close contact with the advisory and extension service. In this connection much effort was and still is being paid to updating regularly the Dutch Table on feedstuffs (first issue in 1939), the Manual for the calculation of the nutritive value of roughages (first issue in 1958) and the Short table on feeding standards for farm animals and nutritive value of feedstuffs (first issue in 1939, now having its 33rd edition). 